\title{
Hubert Bilewicz
}

(Instytut Historii Sztuki, Uniwersytet Gdański)

https://orcid.org/0000-0003-0985-2421

\section{Nostalgia i mizeria socrealizmu. Gertruda Wysocka - przodownica pracy Juliusza Studnickiego jako alegoria realna ${ }^{1}$}

\author{
DOI: https://doi.org/10.26881/porta.2019.18.08
}

„Wbrew wszelkim intuicjom rozwój wizji obrazowej w sztuce przebiega nie na linii powiązań między okiem i wyobraźnią artysty a światem, który go otacza, lecz na szlakach wiodących od jednego dzieła sztuki do następnego [...]; każde konkretne dzieło sztuki rodzi się z innego dzieła czy innych dzieł, zawierających rozpoznane w nim pokrewne tendencje generalne lub choćby cząstkowe. Sztukę rodzi przede wszystkim sama sztuka"2.

Namalowana w 1950 r. przez Juliusza Studnickiego Gertruda Wysocka - przodownica pracy to obraz nietypowy, nieoczywisty i niepokojący (il. 1). Spośród większości przeraźliwie schematycznych i miernych artystycznie polskich obrazów socrealistycznych wyróżnia się nieprzeciętną kulturą malarską, niebanalnym ujęciem oraz nieczęstą dla ówczesnej produkcji obrazowej niejednoznacznością. ${ }^{3}$ Co prawda kultura plastyczna realizmu socjalistycznego - jak zauważył Wojciech Włodarczyk - potrzebowała raczej sprawdzonych w propagandowej pragmatyce przedmiotów, a nie obrazów czy sztuki w ogóle, nie twórców. „Artysta tej kultury nie wypełniał tradycji, nie dostrzegał w niej twórczych możliwości. Wypełniał kolejnymi obrazami miejsca zupełnie innego porządku, wymyślonego przez polityków, a nie z możliwościami tkwiącymi w tradycji”". Ale Gertruda Wysocka - przodownica pracy jest inna.

Poniższy tekst jest rozszerzoną wersją artykułu opublikowanego w katalogu wystawy poświęconej malarstwu Juliusza Studnickiego, odbywającej się w Muzeum Sopotu od 25 stycznia do 31 marca 2015 r., por. Hubert Bilewicz, Nostalgia i mizeria socrealizmu: „Gertruda Wysocka - przodownica pracy” Juliusza Studnickiego jako alegoria realna [w:] Juliusz Studnicki (1906-1978). Twórcy izałożyciele szkoły sopockiej, red. Andrzej Zagrobelny [katalog wystawy], Muzeum Sopotu, Sopot 2015, s. 28-35.

2 Zdzisław Kępiński, Impresjoniści u źródeł swoich obrazów, Wrocław 1976, s. 8.

3 Por. Tadeusz Dobrowolski, Nowoczesne malarstwo polskie, t. 3, Wrocław 1964, s. 416-417; Oblicza socrealizmu, red. Maryla Sitkowska, [katalog wystawy] Muzeum Narodowe w Warszawie, Warszawa 1987, s. 52, poz. 266; Jerzy Ilkosz, Malarstwo realizmu socjalistycznego w Polsce [w:] Sztuka polska po 1945 roku. Materiały Sesji Stowarzyszenia Historyków Sztuki, Warszawa, listopad 1984, Warszawa 1987, s. 206, il. 11; Zofia Tomczyk-Watrak, Wybory i przemilczenia. Od szkoly sopockiej do nowej szkoly gdańskiej, Gdańsk 2001, s. 21-23; Elżbieta Kal, Malarstwo gdańskie 1945-1959. Ludzie, słowa i obrazy, Słupsk 2009, s. 47-48; Andrzej Zagrobelny, Życie i twórczość Juliusza Studnickiego (1906-1978), mpis pracy mgr napisanej pod kierunkiem Joanny Sosnowskiej, Gdańsk 2010, s. 97-101.

4 Wojciech Włodarczyk, Socrealizm. Sztuka polska w latach 1950-1954, Kraków 1991, s. 116. 


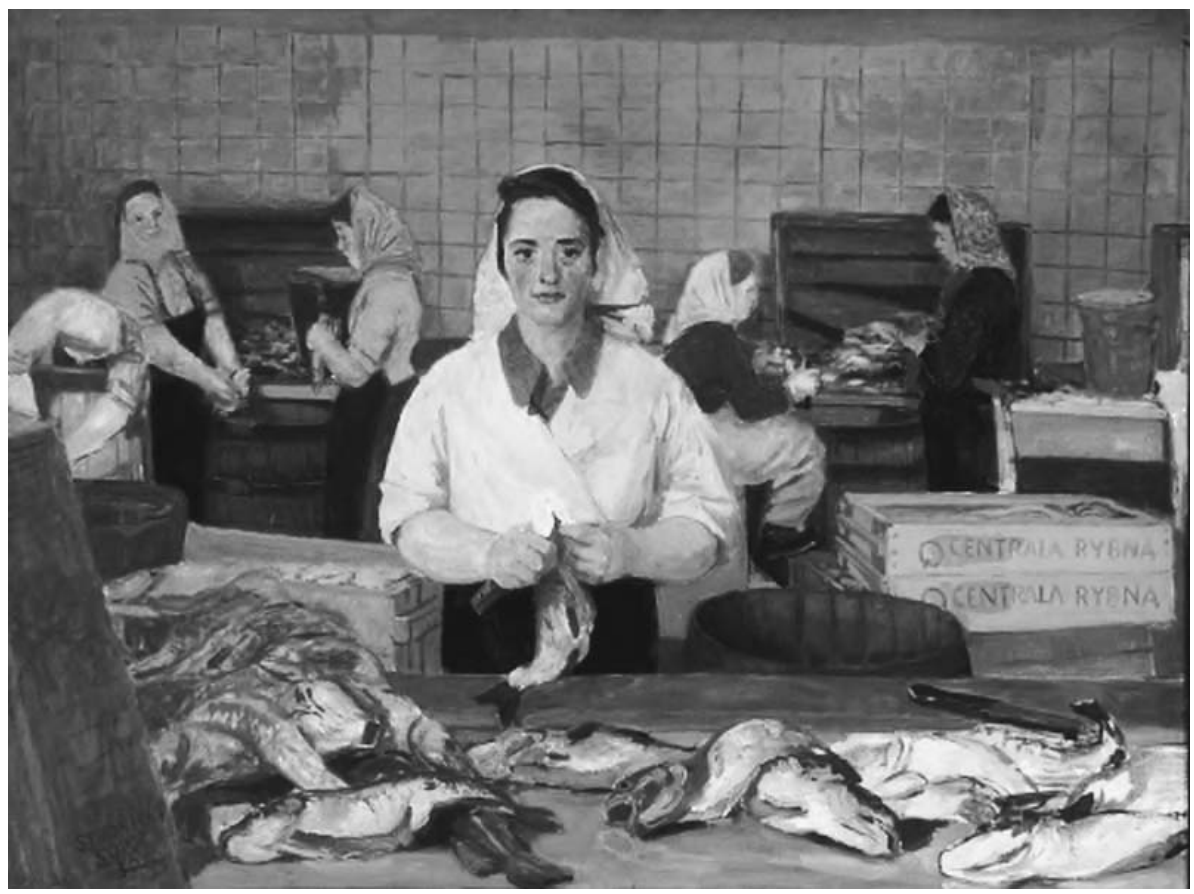

Nostalgia

i mizeria

socrealizmu...

Il. 1. Juliusz Studnicki, Gertruda Wysocka - przodownica pracy, 1950, olej, płótno, $108 \times 137 \mathrm{~cm}$, Muzeum Narodowe w Warszawie, fot. ze zbiorów autora

Nie interesuje mnie przy tym sama portretowana - ani jako osoba, ani jako pracownica Centrali Rybnej pozująca Studnickiemu, będąca na tę okoliczność jego modelką. Nie interesuje mnie też w gruncie rzeczy sam artysta oraz możliwe w tym określonym historycznym kontekście pytania natury moralistyczno-biograficznej, jak to: „,o decydowało o fakcie, że pewni artyści czy intelektualiści znajdowali w sobie tyle siły, by socrealizmowi się oprzeć, inni zaś - czasem wybitni, a może nawet wybitniejsi - z takim czy innym nasileniem i gorliwością mu ulegli"'. Interesuje mnie sam obraz, socrealistyczny artefakt, którego sens nie wyczerpuje się przecież ani w mimetycznym iluzjonizmie czy podobieństwie portretowanej osoby, ani w historycznym aspekcie bycia wizualnym źródłem i dokumentem czasu i miejsca, ani też wreszcie we wpisaniu się w ikonograficzny szereg przedstawień przodowników pracy. Interesuje mnie obraz jako artystyczna reprezentacja, która nie tylko odzwierciedla rzeczywistość, lecz także ją współtworzy, która nie tylko referuje świat przedstawiony, lecz także konstruuje nowy, „wspanialszy” świat rzeczywistości artystycznej. Interesuje mnie zatem - powtórzę - reprezentacja ukazująca zarówno indywidualność przedstawionej postaci, jak i - poprzez malowidło - obszar artystycznych

5 Michał Głowiński, Kierunek: wielka nomenklaturowa chałtura [w:] idem, Rytuał i demagogia. Trzynaście szkiców o sztuce zdegradowanej, Warszawa 1992, s. 163. 
Hubert nawiązań, ujawnianych bądź kamuflowanych odniesień do malarskiej tradycji, Bilewicz podzielanych przekonań czy wyznawanych hierarchii estetycznych, stosowanych strategii twórczych. Dzieło to bowiem zanurzone jest szczególnie w przestrzeni intertekstualnych odniesień, międzyobrazowych zależności, wizualnych paraleli czy artystycznego dialogu z innymi dziełami.

\section{Spojrzenie}

Obraz, w formacie leżącego prostokąta, przedstawia wnętrze oczyszczalni ryb z kobietami przy pracy. Spoglądamy na nie sponad usłanego rybimi tuszami stołu, za którym stoi wpatrzona w nas kobieta patrosząca rybę. Jej ustawiona prawie osiowo postać stanowi centrum kompozycyjne obrazu dzięki optycznej dominancie jasnej plamy. Gertruda Wysocka, ubrana w biały fartuch z podwiniętymi do łokci rękawami, ukazana jest frontalnie, widoczna w półfigurze, przepasana ochronnym czarnym fartuchem, na głowie ma białą chustę odsłaniającą czarne włosy asymetrycznie okalające wysokie czoło. Mimo że w ułożonych horyzontalnie, poniżej piersi, pulchnych rękach trzyma rybę i nóż, to zarówno jej twarz o prawie kwadratowym kształcie, jak i wyraziście oprawione, ciemne oczy skierowane są wprost na widza. Tę „zwyczajną” twarz, o prostym, dość szerokim nosie i dużych ustach, ożywiają czerwone wypieki na policzkach. Za plecami przodownicy pracy, patroszarki z Centrali Rybnej, widzimy w oddaleniu, na tle szarej, wykafelkowanej ściany pięć kolejnych kobiet zajętych podobnymi czynnościami. Wnętrze ukazane zostało z nieznacznie podwyższonego punktu, z zastosowaniem perspektywy zbieżnej. W wyraźnie podzielonej na trzy równoległe plany kompozycji dominują linie horyzontalne. Sylwetka kobiety, ujęta w kształt domyślnego trójkąta równobocznego, wyraźnie scala plany. Rozproszone chłodne światło równomiernie wydobywa kolejne elementy kompozycji, eksponując jasność użytych bieli w tonalnym kontraście z utrzymaną zasadniczo w monochromatycznej gamie całością kompozycji. Kolorystyka płótna jest zgaszona, choć o nieco pastelowym wyrazie, $\mathrm{w}$ szarościach $\mathrm{z}$ akcentami różu, skontrastowanymi temperaturowo z cieplejszymi brązami i przełamanymi zgniłą zielenią ugrami, wzbogaconymi kilkoma akcentami plam ciepłej zieleni i błękitów (subtelnie ukazanych zwłaszcza w partii ściany). Obraz został namalowany swobodnie, szerokimi płaszczyznami, dość sumarycznie, niekiedy zamaszystymi, nieco nonszalanckimi, niemniej zdecydowanymi gestami pędzla, z kilkoma partiami ujętymi w niemalże szkicowy, lecz finezyjny sposób. Faktura jest zróżnicowana, ukazana odważnie, zwłaszcza w wirtuozowskich przedstawieniach leżących na stole kilkunastu rybich tuszy: od gęstych impastowych plam oleistej farby, przez „suche”, szkicowe bądź wyglądające na malowane „akwarelowo” fragmenty odsłaniające teksturę zagruntowanego płótna, aż po ołówkowe linie rysunku przygotowawczego. 
Gdyby próbować zamknąć specyfikę tego przedstawienia w lapidarnej formule, to można by stwierdzić: kobieta na nas patrzy. Zajęta jest nie tyle patroszeniem ryb, ile odpowiedzią na nasze spojrzenie, chęcią nawiązania kontaktu $\mathrm{z}$ widzem. Od przestrzeni obserwatora oddziela ją jednak blat stołu z rybami oraz, w lewym dolnym narożniku, wertykalny fragment drewnianej, stojącej ukośnie skrzyni. Jest to element najbliższy nam w iluzji trójstopniowej głębi namalowanego wnętrza, odsyłający do przestrzeni pozaobrazowej, zawierający ostentacyjną sygnaturę: „STUDNICKI / SOPOT / 50”. Stół stanowi pierwszy z czterech horyzontalnych pasów kompozycji. Kolejny obejmuje sylwetkę kobiety (do wysokości ramion) oraz otaczające ją skrzynie na ryby (na ściankach dwóch widoczny jest zdublowany napis: „Q CENTRALA RYBNA”) i beczki na odpadki. Trzeci pas wypełniony jest postaciami pozostałych pięciu kobiet namalowanych w tle wraz ze skrzynkami, beczkami i wiadrami; obejmuje równocześnie głowę głównej bohaterki, która wyznacza ten prawie izokefaliczny układ, „spinając” swą figurą wszystkie poziome pasy, łącznie z tym ostatnim, określonym płaszczyzną wykafelkowanej ściany.

Szczególną uwagę skupia twarz kobiety. Poza wskazuje na chwilę oderwania od monotonnej czynności. To raczej celebracja chwili lub zawieszenie, efekt domniemanej prośby patrzącej na nią osoby (malarza?, fotografa?, widza?) o chwilowe spojrzenie, jednak bez porzucania pracy, która ją zajmuje. Trudno odnaleźć na jej ustach uśmiech ${ }^{6}$, nie jest też nawet „lekko uśmiechnięta”. I trudno dostrzec w tym obrazie ideologię, partyjność, typowość, obowiązkowy optymizm, romantyzm pracy czy pokojowej rywalizacji ${ }^{8}$, właściwy sztampowym ujęciom socrealistycznym. Obraz wyróżnia się na tle ówczesnych prac o tematyce produkcyjnej9. To bardziej portret kobiety niż rodzajowy wizerunek przodownicy pracy, lecz również martwa natura z rybami i... kobietą.

$\mathrm{Na}$ szczególną rolę portretu dla sztuki realizmu socjalistycznego, obok kompozycji figuralnych, zwracał uwagę przy okazji I Ogólnopolskiej Wystawy Plastyki Juliusz Krajewski - jeden z postulatorów i solenny praktyk doktryny socrealistycznej w Polsce - i jednocześnie przestrzegał: „Zaniedbanie strony psychologicznej portretowanej osoby, umowne lub pobieżne traktowanie elementów drugoplanowych obrazu, wyizolowanie portretowanego człowieka $\mathrm{z}$ otaczającego go środowiska, wszystko to wpływa na osłabienie ekspresji obrazu, sprowadzając problem do fizycznego podobieństwa wyobrażonego człowieka. [...] Portret [...] winien stać się portretem naszej epoki, mówiącym o bohaterstwie indywidualnym człowieka pracy, o przodującej roli klasy robotniczej, o wielkim dziele budowy socjalizmu. Zadanie to wymaga znalezienia nowych właściwych środków wyrazu, nowych właściwych zasad kompozycji portretu,

Por. Kal, Malarstwo gdańskie..., s. 47.

Zagrobelny, Życie i twórczość Juliusza Studnickiego..., s. 98-99.

Kal, Malarstwo gdańskie..., s. 47.

9 Por. Jolanta Studzińska, Socrealizm w malarstwie polskim, Warszawa 2014, s. 306-310, 313-316 (ikonografia przodowników pracy). 
Hubert wymaga poznania i przemyślenia każdego indywidualnego problemu, nasuwaBilewicz jącego się w konkretnym portrecie" ${ }^{\prime 10}$.

\section{Egzystencjalna hermeneutyka portretu}

Próbując wyjaśnić specyfikę portretowego przedstawienia, musimy odróżnić portret jako obraz i portret jako dzieło sztuki oraz mieć świadomość relacji między pierwowzorem/podobizna a indywiduum ${ }^{11}$. Tym samym za specyficzną treść portretu można by uznać biografię portretowanej, zaś sam portret potraktować jako dokument życia, dający widzowi szczególne poczucie, że obcuje $\mathrm{z}$ realną postacią. „W przypadku portretu obraz jest przedstawieniem bardziej niż w jakimkolwiek innym rodzaju malarstwa" - pisze jedna $\mathrm{z}$ badaczek, a specyficzna sytuacja widza, wynika z tego, że zajmuje on „miejsce naprzeciw wizerunku drugiego człowieka” ${ }^{12}$. „Stojąc przed portretem - dziełem sztuki - pisze inny badacz - widz doświadcza oglądowego synonimu tego, czym człowiek jest jako taki. Prezentując się jako integralne, dzieło sztuki portretowej ukazuje postać »jak całość « - zatem to, na czym polega jej niepodzielność, czyli bycie indywiduum jako takim. Ukazywanie to wydarza się między obrazem a widzem, nie ujawnia więc indywiduum modela, pierwowzoru. Co więcej, poznawane $\mathrm{w}$ doświadczeniu indywiduum jest raczej zaprzeczeniem tego, kim ów model, i my sami, czyli ludzie rzuceni w świat, na co dzień jesteśmy - kimś, kto jest uwikłany w przestrzenne relacje ze światem i w rzeczywistość poręcznych narzędzi, służących pracy i reprezentacji. Jako taki portret będący dziełem sztuki wyzwala się ze swej gatunkowej przynależności”"13.

Można by także zapytać, podążając za tyleż sugestywnymi, co oksymoronicznymi pytaniami stawianymi przez Williama Johna Thomasa Mitchella: Czego zatem pragnie ten obraz? Czego od nas żąda? Czego potrzebuje? „Weźmy typowy portret wiszący w galerii portretu obok setek innych, czekający aż ktoś zwróci nań uwagę. Przeciętny portret - konwencjonalny, oficjalny obraz zapomnianej osobistości zapomnianego malarza - jest najbardziej opuszczoną figurą tęsknoty za rozpoznaniem"14. Tyle że Gertruda Wysocka - przodownica pracy ani przeciętnym, ani konwencjonalnym portretem nie jest! Animistyczna ikonologia Mitchella ma chyba w tym wypadku swój szczególny sens.

10 Juliusz Krajewski, I Ogólnopolska Wystawa Plastyki, „Przegląd Artystyczny” 1950, nr 5-6, s. 19.

11 Por. Michał Haake, Portret w malarstwie polskim u progu nowoczesności, Kraków 2008, s. 17-43; Agnieszka Skalska, „Dziewczynka z chryzantemami” Olgi Boznańskiej - osaczona. Uwagi o spojrzeniu, „Artium Quaestiones” 1995, nr 7, s. 141-151.

12 Ibidem, s. 142.

13 Haake, Portret $w$ malarstwie..., s. 326.

14 W.J.T. Mitchell, Czego chca obrazy?, Warszawa 2013, s. 102. 
Kulturową płeć obrazów postrzega się „domyślnie” jako kobiecą. Wedle Norsocrealizmu... mana Brysona „konstruuje ona relację oglądania wokół opozycji pomiędzy kobietą jako obrazem a mężczyzną jako tym, komu przynależy patrzenie"15. Nie dziwi zatem wynikająca stąd konstatacja Mitchella: „Pytanie, czego chcą przedstawienia wizualne, jest więc nieodłączne od pytania, czego chcą kobiety" 16 . Stereotypowa relacja - zidentyfikowana lapidarnie w aforystycznym sformułowaniu Johna Bergera - zakładała, że „mężczyźni działają, zaś kobiety objawiają się"17; inaczej można by rzec: mężczyźni patrzą, kobiety prezentują się, poddając się władzy ich spojrzenia. „Postacie kobiece jako wytwór męskiej wyobraźni są jedynie obiektami wystawionymi na pokaz, wystylizowanymi tak, aby wywierać silne wrażenie wizualne na mężczyznach"18. Ale w tym wypadku owo „naturalnie” męskie spojrzenie natrafia na wzrok kobiety. Jej twarz i sylwetka zdają się bardziej wyrażać świadome „panowanie” nad widzem, a może nawet zdystansowaną autonomię, niż podporządkowaną widzowi prezentację ${ }^{19}$.

Obraz powstał w tym samym roku, w którym namalowano najsłynniejsze chyba polskie dzieła socrealistyczne: Podaj cegłę i Ceglarki Aleksandra Kobzdeja, Podziękowanie traktorzyście Juliusza Krajewskiego czy Manifest Wojciecha Weissa. Nie pokazano go jednak ani na I Ogólnopolskiej Wystawie Plastyki, ani na kolejnej. Zaprezentowano go dopiero na wystawie „Plastycy w walce o pokój”, zorganizowanej w warszawskiej Zachęcie ${ }^{20}$.

Ikonografia socrealistyczna eksponowała „tytaniczny charakter dążeń jej sztandarowych postaci”21. „Zadania, jakie stawiają sobie artyści malujący portrety przodowników pracy i racjonalizatorów, są zadaniami trudnymi. Przecież tu pozują ludzie wielkiej siły i charakteru - nowi ludzie nowej epoki. Trzeba więc malować ich takimi, jakimi są, a nie tylko tak, aby byli do siebie podobni” - pisał

15 Cyt. za: Mitchell, Czego chca obrazy..., s. 70.

16 Ibidem.

17 John Berger, Sposoby widzenia, Poznań 1997, s. 47.

18 Małgorzata Radkiewicz, Władza spojrzenia [w:] Encyklopedia gender. Płeć w kulturze, red. Monika Rudaś-Grodzka i in., Warszawa 2014, s. 567.

19 Należy zauważyć, że poza postacią tytułowej bohaterki kontakt wzrokowy z widzem nawiązuje również jedna $\mathrm{z}$ kobiet $\mathrm{w}$ tle, przy lewej krawędzi obrazu.

20 Obraz wystawiono po raz pierwszy w warszawskiej Zachęcie na ogólnopolskiej wystawie „Plastycy w walce o pokój” (18 listopada - 22 grudnia 1950 r.), zorganizowanej w związku z II Światowym Kongresem Obrońców Pokoju, gdzie Studnickiego uhonorowano III nagrodą. Następnie pracę pokazano na IV Festiwalu Plastyki w Sopocie (1 lipca - 19 lipca 1951 r.), por. Polskie życie artystyczne w latach 1944-1960, red. Anna Wierzbicka, t. 4, Rok 1950, oprac. Przemysław Strożek, Warszawa 2012, s. 214-223, 229. Zob. też Plastycy polscy w walce o pokój, „Słowo Ludu” 1950, nr 322, s. 6 (il.); Janusz Bogucki, Wystawa „Plastycy w walce o pokój”, „Przegląd Artystyczny” 1951, nr 1, s. 26-27 (il.).

${ }_{21}$ Zbigniew Kaźmierczyk, Ewolucja romantycznego tytanizmu w ikonografii socrealistycznej - na przykładzie utworów Aleksandra Ścibora-Rylskiego [w:] Socrealizm. Fabuły - komunikaty - ikony, red. Krzysztof Stępnik, Magdalena Piechota, Lublin 2006, s. 147. 


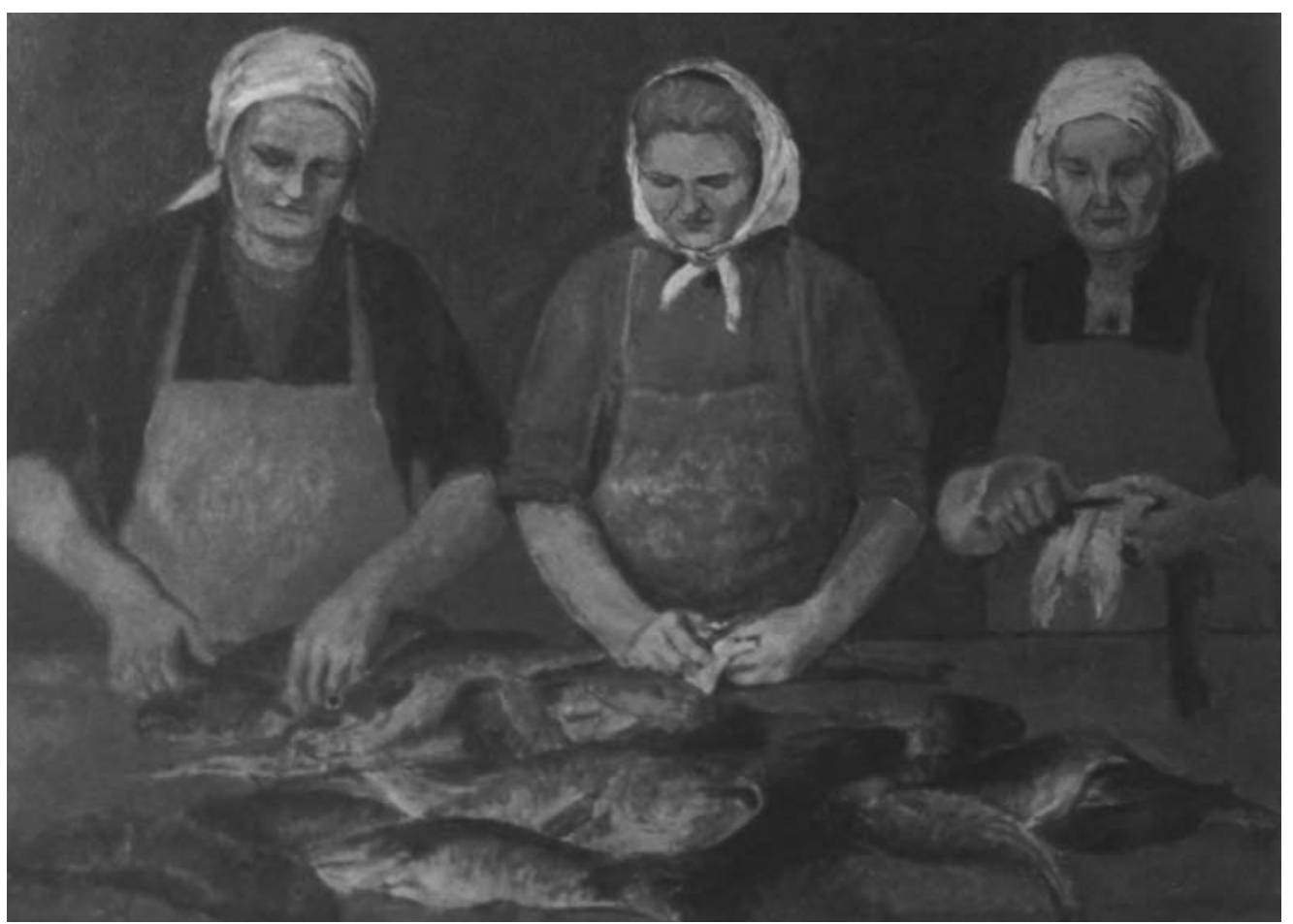

Il. 2. Aniela (Daniela) Droździecka, Praca walczymy, 1950, olej, płótno, miejsce przechowywania nieznane, repr. za: Polskie życie artystyczne w latach 1944-1960, red. Anna Wierzbicka, t. 4, Rok 1950, oprac. Przemysław Strożek, Warszawa 2012, il. 34

z emfazą ówczesny sprawozdawca 22 (il. 2). Nie bez powodu figury socjalistycznych heroin, przodowniczek pracy można kryptonimować - jak uczyniła to Ewa Toniak - w zastępczej alegorii olbrzymki²3 (il. 3). Z kolei Agata Araszkiewicz pisze: „Kobieta, »męski« heros, pełni rolę cichej robotnicy, przebywającej za kulisami i podtrzymującej totalitarny porządek. Jej emancypacja staje się faktem nie tyle świadomym, ile mechanicznym, odgórnie kontrolowanym i nadużywanym"24. Typ obrazowy przodownika pracy wpisano w propagandowy aksjomat wyobrażenia najwłaściwszego wzorca: „pioniera postępu, świadomie doskonalącego swój warsztat pracy i aktywnie współtworzącego nowe społeczno-gospodarcze oblicze socjalistycznej ojczyzny"25. Jednocześnie na zasadzie dokładnego przeciwieństwa

22 Stefan Rassalski, Wystawa Przodowników Pracy, „Stolica” 1950, nr 31, s. 9; cyt za: Polskie życie artystyczne..., s. 152.

23 Ewa Toniak, Olbrzymki. Kobiety i socrealizm, Kraków 2008.

24 Agata Araszkiewicz, Kobieta z marmuru [w:] Maria Papa Rostkowska. Kobieta z marmuru [katalog wystawy], Warszawa 2014, s. 57.

${ }_{25}$ Por. Hubert Wilk, Ludzie z marmuru. Proces awansu i degradacji przodowników pracy (1947-1955); Magdalena Dzienis, Przyczynek do badania wizerunku kobiety-robotnicy, przodowniczki pracy w prasie w okresie realizacji Planu 6-letniego [w:] Współzawodnictwo pracy w życiu 
wymodelowany został propagandowy wizerunek robotnika kapitalistycznego, przedstawianego jako bezwolny dodatek do maszyny, ślepo wykonujący narzucone mu zadania produkcyjne"26. $\mathrm{W}$ dyskursie socjalistycznym pracą sensu stricto była praca produkcyjna ${ }^{27}$, chociaż dość oczywiste wydają się jej analogie z pracą domową: „monotonia i powtarzalność pracy domowej nie różni jej od pracy przy taśmie w fabryce..." ${ }^{28}$. Toniak spostrzegła ponadto $\mathrm{w}$ zestawieniu dwóch wspomnianych powyżej obrazów Aleksandra Kobzdeja, Podaj cegłę i Ceglarek, powstałych zresztą $\mathrm{w}$ tym samym sopockim środowisku, że „pozycja kobiet, niezaangażowanych w proces budowania »lepszego jutra «, mechanicznie umieszcza je po stronie "wroga «, wbudowując w obraz jeszcze jedną parę opozycji binarnych i obciążając stronę »kobiecą" dodatkowym nega-

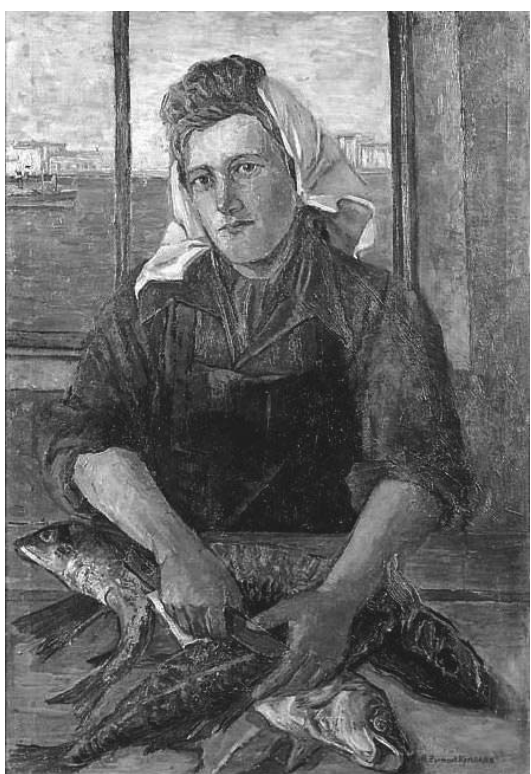

Il. 3. Helena Żyrmont-Korklińska, Portret przodownicy pracy Ob. Hauptówny Elżbiety, 1950, olej, płótno, $103 \times 72 \mathrm{~cm}$, zbiory prywatne; fot. ze zbiorów autora
Nostalgia i mizeria socrealizmu... tywnym znaczeniem" ${ }^{29}$.

\section{Gra z socrealizmem}

Przyjmuje się, że narzucane przez politykę i doktrynę socrealizmu normy oraz wzorce były przez artystów modyfikowane, a nawet pomijane, stając się polem dla indywidualnej, twórczej interpretacji oraz pokazem "chwytów”, którymi „artysta modyfikował, »ukulturalniał« socrealistyczny obraz, nie mogąc - ze względu na specyfikę tamtych czasów - jawnie z socrealizmem polemizować” ${ }^{\prime 3}$. Artyści w różnoraki sposób próbowali radzić sobie z socre-

gospodarczym, społeczno-politycznym i propagandzie PRL, red. Bogusław Tracz, Warszawa 2008; Hubert Wilk, Kto wyrabie więcej ode mnie? Wspótzawodnictwo pracy robotników w Polsce w latach 1947-1955, Warszawa 2011; Małgorzata Fidelis, Kobiety, komunizm i industrializacja w powojennej Polsce, Warszawa 2015; Padraic Kenney, Budowanie Polski Ludowej. Robotnicy a komuniści 1945-1950, Warszawa 2015.

26 Małgorzata Jarmułowicz, Przodownika pracy obraz [w:] Słownik realizmu socjalistycznego, red. Zdzisław Łapiński, Wojciech Tomasik, Kraków 2004, s. 240.

27 Sławomira Walczewska, Damy, rycerze i feministki. Kobiecy dyskurs emancypacyjny w Polsce, Kraków 2006, s. 86.

28 Ibidem, s. 89.

29 Toniak, Olbrzymki..., s 24.

30 Włodarczyk, Socrealizm. Sztuka polska..., s. 120. 
Hubert alizmem, zajmując rozmaite postawy wobec politycznego dyktatu ${ }^{31}$. Nieliczni Bilewicz milczeli, inni praktykowali swoistą grę z systemem. „Wielu twórców - pisze Andrzej Friszke - zachowywało bowiem znaczny procent wewnętrznej suwerenności, pragnienie wypowiedzenia własnej subiektywnej prawdy, budowania możliwie doskonałego warsztatu i przekazywania następcom nieocenzurowanej wiedzy o wykonywanym rzemiośle. Poruszając się w ograniczonych systemem ramach, próbowali je przełamywać, a tym samym osłabiali spójność owych ram i przyczyniali się do poszerzania zakresu wolności. Istnienie w oficjalnym obiegu życia kulturalnego pociągało za sobą koszty - zależnie od okresu i dyscypliny większe lub mniejsze - lecz alternatywą było milczenie, niebyt, umysłowa pustynia i przerwanie ciągłości kultury narodowej”32.

\section{Jaki realizm?}

Michał Głowiński zauważył (co prawda na gruncie literackim, choć taką konstatację można również przenieść na obszar sztuk wizualnych), że odwoływanie się do dziewiętnastowiecznego realizmu miało „uwierzytelniać i legitymizować w oczach naiwnego czytelnika tę wizję świata, która od początku do końca była propagandowym nadużyciem. $\mathrm{W}$ ten sposób ukształtowała się jedna $\mathrm{z}$ form totalitarnych o najszerszym kręgu oddziaływania, w wysokim stopniu skonwencjonalizowana i najbliższa technikom propagandowym, które zyskały moc obowiązującą w sferze oddziaływania stalinizmu”. I dodawał : „socrealizm to była jakby [...] realizacja tej reguły, która pozwala kreować świat fikcyjny, świat ideologicznego zmyślenia - i traktować go tak, jakby był światem rzeczywistym" ${ }^{33}$. Francuscy realiści XIX stulecia (Emil Zola nazwał ich nawet „aktualistami”) uważali, że jedynym tematem godnym współczesnego artysty jest świat współczesny $^{34}$, a zadaniem realistycznych obrazów jest jego ukazywanie: „... oto jest to, co jest tam, gdzie jest, i wtedy, kiedy jest - i nic poza tym"35. Redukowano bądź eliminowano tym samym tradycyjne czynniki moralizatorskie, ograniczano też rolę elementów psychologicznych czy metafizycznych ${ }^{36}$. Ponadto - jak pisał Zdzisław Kępiński - przypominając dyrektywę Zoli, że sztuka ma być obrazem natury oglądanej przez pryzmat temperamentu, „musimy jasno uświadomić sobie, że autor tej dewizy miał na myśli nie żadne przelotne emocje czy nastroje, lecz starożytne i przez całe wieki używane pojęcia o czterech temperamentach

31 Maryla Sitkowska, Czytanie między obrazami, „Res Publica” 1987, nr 4, s. 37; cyt za: Toniak, Olbrzymki..., s. 12, przyp. 11.

32 Andrzej Friszke, Przystosowanie i opór. Rozważania nad postawami społecznymi 1956-1970 [w:] idem, Przystosowanie i opór. Studia z dziejów PRL, Warszawa 2007, s. 137-138.

33 Michał Głowiński, Realizm i demagogia [w:] idem, Rytuał i demagogia, s. 17.

34 Linda Nochlin, Realizm, Warszawa 1974, s. 32, 30.

35 Ibidem, s. 37-38.

36 Ibidem, s. 34. 
lub czterech kompleksjach, czyli w terminologii dzisiejszej o czterech konstytucjach psychofizycznych" ${ }^{37}$. Czy malowany przez Studnickiego portret spełniał te dyrektywy?

\section{Oczyszczalnia ryb versus bar}

W czasie, gdy powstawał obraz Studnickiego, powszechnie przyjmowano, że „schemat rządzący układem postaci występujących w socrealistycznym obrazie »ściągany « bywał zazwyczaj z malarstwa dawnych mistrzów" 38 .

Dla ówczesnych odbiorców w obrazach Studnickiego czytelne były (choć niekoniecznie eksplicytnie dosłownie nazywane) nawiązania do sztuki francuskiej, zwłaszcza do twórczości Edouarda Maneta, zasadniczo różne od postimpresjonistycznych fascynacji malarstwem Paula Cézanne’a, Pierre’a Bonnarda, Edouarda Vuillarda czy Camille’a Pissarra, właściwych dla twórczości artysty w okresie międzywojennym ${ }^{39}$. Dobitnie formułował to Kępiński, poznański historyk sztuki i wieloletni dyrektor tamtejszego Muzeum Narodowego, bliski środowisku artystów sopockich, mający z nimi osobiste kontakty i legitymizujący poniekąd legendę szkoły sopockiej ${ }^{40}$ : „Zdarza się w praktykach malarzy o postępowych tendencjach, że ujęcie obrazowe w jakimś sławnym dziele przeszłych czasów nasuwa im pomysł podjęcia nie tylko tematu, ale i osnowy kompozycyjnej dla ukazania, jak przedstawione tam wydarzenia, akcja czy też problem rysują się w świetle prawdy głębszej i pełniejszej niż ta, która dostępna była poznaniu dawnych epok"41.

Gertruda Wysocka - przodownica pracy jest reminiscencją i parafrazą Baru $w$ Folies-Bergère - ostatniego wielkiego obrazu Maneta ${ }^{42}$ (il. 4). Z pewnością reminiscencją nieskonwencjonalizowaną, jak wyrażała się o niej po latach Elżbieta Grabska, recenzentka szkoły sopockiej jeszcze w latach pięćdziesiątych ${ }^{43}$. Obraz Maneta, przedstawiając barmankę, oddzieloną od widza kontuarem zastawionym butelkami i owocami, oraz wielką taflę lustra, którą kobieta ma za plecami, ukazuje de facto odzwierciedloną przestrzeń baru, wraz z odbiciem postaci klienta w górnym prawym rogu obrazu. Praca ta, badając relację między realnością a iluzją

37 Kępiński, Impresjoniści u źródeł..., s. 64.

38 Włodarczyk, Socrealizm. Sztuka polska..., s. 125.

39 Dobrowolski, Nowoczesne malarstwo polskie..., s. 417-418. Por. Andrzej Zagrobelny, Twórczość Juliusza Studnickiego w okresie dwudziestolecia międzywojennego, „Porta Aurea” 2012, t. 11, s. 301-319.

40 Por. wstęp Kępińskiego do rocznicowej publikacji Państwowa Wyższa Szkoła Sztuk Plastycznych w Gdańsku, 1945-1965, red. Józefa Wnukowa [b.m., b.d.].

${ }^{41}$ Kępiński, Impresjoniści u źródeł..., s. 31.

42 Bar w Folies-Bergère, 1881-1882, olej, pł., $96 \times 130 \mathrm{~cm}$, Courtauld Institute of Art Gallery, Londyn, por. Timothy James Clark, The Painting of Modern Life. Paris in the Art of Manet and His Followers, Princeton 1999, s. 250-258.

43 Elżbieta Grabska, „Puisque réalisme il y a”, czyli o tym co $w$ sztuce powojennego dziesięciolecia nie mogło się dokonać [w:] Sztuka polska po 1945 roku. Materiały Sesji Stowarzyszenia Historyków Sztuki, Warszawa, listopad 1984, Warszawa 1987, s. 376. 


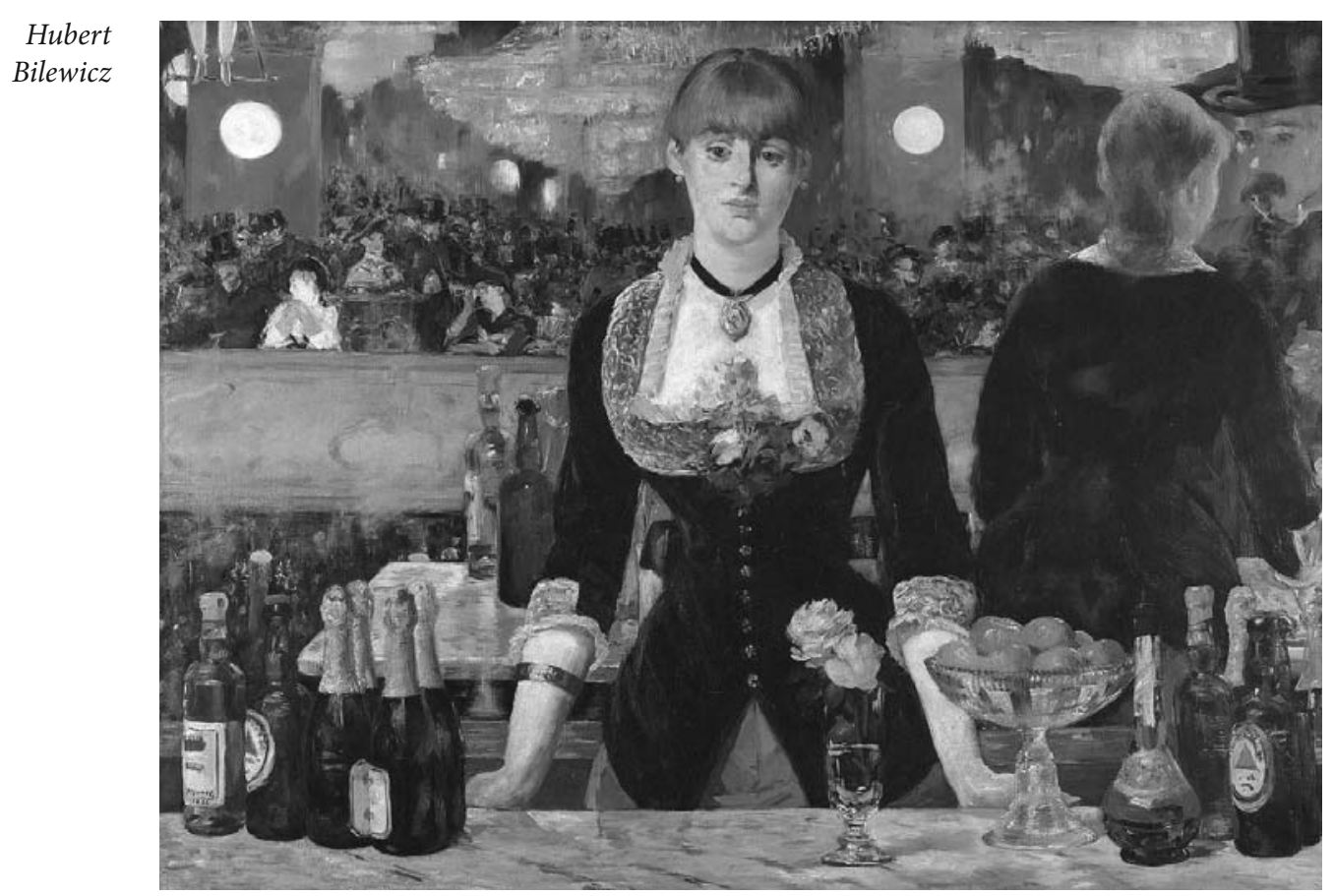

Il. 4. Édouard Manet, Bar w Folies-Bergère, 1881-1882, olej, płótno, $93 \times 130$ cm, Courtauld Gallery w Londynie; repr. za: Wikipedia

w malarstwie figuratywnym, prezentując kolejne, nałożone na siebie warstwy wyobrażonej „realności”, poddaje się równocześnie możliwościom lektury alegorycznej i stanowi „być może najostrzejsze wyobrażenie alienacji, jakie kiedykolwiek namalowano" - jak to sugestywnie określiła Linda Nochlin ${ }^{44}$. Alienacji? Izolacji od świata oddających się uciechom paryskich konsumentów odbijających się w lustrze? Samotności wśród paryskiego tłumu? „Nieobecnej” obecności? Pozostawania obserwatorką, nie zaś uczestniczką wydarzeń? Apatii? A może nostalgii? ${ }^{45}$ Etymologia tego ostatniego słowa oznaczającego doskwierającą tęsknotę za czymś przeszłym zawiera bowiem w sobie zbitkę greckich terminów, które oznaczają powrót oraz ból.

\section{„Alegoria”?}

Funkcją alegorii jest obrazowe przedstawienie jakiejś abstrakcyjnej idei czy uogólnienia, najczęściej zresztą $\mathrm{w}$ formie personifikacji. Jej czytelność zasadza się na dwóch warstwach znaczenia: dosłownym oraz przenośnym, a relacja

44 Linda Nochlin, The Invention of the Avant-Garde [w:] eadem, The Politics of Vision. Essays on Nineteenth-Century Art and Society, New York 1989, s. 17.

${ }_{45}$ Albert Boime, Manet's „Un bar aux Folies-Bergère” as an Allegory of Nostalgia, „Zeitschrift für Kunstgeschichte" 1993, nr 2, s. 234-248. 
między nimi, uwarunkowana tradycją kulturową, ma charakter konwencjonalny i jednoznaczny ${ }^{46}$. Ścisłe osadzenie alegorii w tradycyjnych praktykach kulturowych prowadziło jednak, wraz z procesami modernizacyjnymi, rozluźniającymi konwencjonalne mechanizmy obrazowania, do stopniowej utraty jej znaczenia, jako figury o zbyt rygorystycznym i zwyczajowym charakterze. „W krytyce feministycznej podkreśla się - jak twierdzi Iwona Kurz - że arbitralny związek dwu warstw znaczeniowych wyraża i jednocześnie utrwala porządek symboliczny i ideologiczny kultury. Tak rozumiana alegoria jest częścią szerszego pola reprezentacji symbolicznej, w której dokonuje się mediacja znaczeń, także tych, które przypisuje się płci, i jest narzędziem dominującej ideologii” ${ }^{47}$. W kulturze patriarchalnej uważano, że kobieta może być nośnikiem rozmaitych pojęć, a pozbawiona własnej osobowości, jest w stanie bez trudu podporządkować się narzuconej woli. Uznawano nawet, że popularność żeńskich personifikacji miała swoje źródło w obiegowym przekonaniu, że przebieranie się w różne stroje (cecha kobieca) konstytuuje i legitymizuje figury obrazowanych kobiet jako szczególne nośniki wielu, często nawet sprzecznych, bo zarówno pozytywnych, jak i negatywnych, wyobrażeń, idei czy uogólnień. Stereotypowe wyobrażenia o niestałości i chwiejności kobiet czy braku indywidualności pozwalały na łatwe wykorzystywanie figur kobiecych jako reprezentacji o przeciwstawnym znaczeniu, np. cnót i przywar, czystości i zepsucia; prawdy i fałszu ${ }^{48}$. Marina Warner, badaczka tego zagadnienia, podkreśla, że „alegoria jest przede wszystkim postulatywną ekspresją pożądanych wartości i cnót. [...] Wskazuje na pewien ideał czy też abstrakcyjne uogólnienie, którego uniwersalna siła w dużej mierze wynika z oderwania wizerunku od indywidualnych losów; w kobiecych alegoriach nie ma miejsca dla rzeczywistych kobiet"49.

Wbrew najczęściej agitacyjnym sensom alegoryki w sztuce dwudziestowiecznej ${ }^{50}$, wbrew stereotypowej ikonografii i tematycznemu schematowi Gertruda Wysocka - przodownica pracy jest tyleż portretem robotnicy, co alegorycznym przedstawieniem indywidualnej nostalgii, a zarazem społecznej i dziejowej mizerii, jednostkowej determinacji, ale też osobistej apatii, społecznej emancypacji, ludzkiej alienacji bądź wreszcie autonomii jednostki zdeterminowanej trybami historii. Griselda Pollock w inspirującej książce Vision and Difference. Femininity, Feminism and the Histories of Art ${ }^{51}$ przyjrzała się przestrzeniom malowanym przez kobiety bądź je przedstawiającym. Autorka przypisuje organizacji pola

46 Iwona Kurz, Alegoria [w:] Encyklopedia gender. Płeć w kulturze, red. Monika Rudaś-Grodzka i in., Warszawa 2014, s. 32-33.

$47 \quad$ Ibidem, s. 33.

48 Por. Marina Warner, Monuments and Maidens. The Allegory of the Female Form, New York 1985.

49 Cyt za: Kurz, Alegoria..., s. 33.

50 Antoni Ziemba, Alegoria [w:] Słownik terminologiczny sztuk pięknych. Wydanie nowe, Warszawa 1996, s. 10.

51 Griselda Pollock, Vision and Difference. Femininity, Feminism and the Histories of Art, London-New York 1988. 
Hubert obrazowego, układowi kompozycyjnemu i podziałom płaszczyzny symbolizoBilewicz wanie granic społecznej egzystencji kobiet ${ }^{52}$. Dostrzega specyfikę przestrzeni feministycznej na takich obrazach, na których „kobieta patrzy i jest oglądana” ${ }^{53}$. Gertruda Wysocka nie ma jednak za sobą lustra odbijającego blichtr i gwar współczesnego życia, lecz ścianę pokrytą kafelkami. Tylko ona, w przeciwieństwie do uwijających się w tle kobiet, zastygła i trwa w zawieszeniu oraz w bezczasowym tęsknym spojrzeniu. Można powiedzieć: wytrwale patrzy. Obojętna? Apatyczna? Wyobcowana? Melancholijna ${ }^{54}$ Pogrążona w tęsknocie? Przytłoczona przez niedolę i niedostatek? Oddzielona od innych i od samej siebie?

A może owa aura nostalgii, tak daleka od większości socrealistycznych wyobrażeń ludzi przy pracy - afirmatywnych ideowo i schematycznych w swym „,nieludzkim" heroizmie - wpisuje właśnie ten obraz w krąg przedstawień melancholii? Jej Freudowskie rozumienie odnosi się do utraty obiektu oraz niezgody na pogodzenie się ze stratą (w przeciwieństwie do jej akceptacji w wyniku procesu żałoby). Melancholicy, to ci, „co nigdy nie odnajdą straty” ${ }^{2}$, są zanurzeni, co prawda, w ludnym i przepełnionym życiem świecie, niemniej pogrążeni w wewnętrznej pustce oraz dojmującym i nigdy nieprzepracowanym poczuciu braku i tęsknoty za czymś, co utracone. Wydaje się, że tak właśnie został przedstawiony Gogol na nieco późniejszym obrazie Studnickiego ${ }^{56}$. Za jeszcze jedną, kolejną w środowisku szkoły sopockiej reminiscencję Manetowskiego Baru w Folies-Bergère można uznać Bar mleczny Józefy Wnukowej z 1954 r. Kompozycyjne i tematyczne paralele z wcześniejszym obrazem Studnickiego włączają to przedstawienie w skomplikowaną sieć intertekstualnych zależności i związków międzyobrazowych (il. 5).

Postrzeganie jednych obrazów przez pryzmat innych obrazów jest zawsze inspirujące. Wydaje się, że nawiązanie Studnickiego do obrazu Maneta było zamierzone i w pełni świadome, spełniając poniekąd rolę malarskiej reminiscencji oraz ideowej parafrazy. Miało charakter zarówno formalny (poprzez organizację pola obrazowego, kompozycję, sposób malowania), jak i tematyczny (portret kobiety powiązany z ikonografią pracy) oraz treściowy (alegoryczne wyobrażenie nostalgii). Inną kwestią pozostaje nieoczywistość takiego ujęcia oraz niedopowiedzenie w sferze znaczeniowej.

Gertruda Wysocka - przodownica pracy budzi zresztą inne pokusy interpretacyjne. Zauważmy, że ambiwalentna symbolika ryb wskazuje na obfitość, płodność, rozrodczość, żeńskość, pełnię życia, lecz równocześnie - poprzez falliczne

Skalska, „Dziewczynka z chryzantemami”..., s. 150.

Ibidem, s. 150-151.

4 Por. Urszula Chowaniec, Melancholia [w:] Encyklopedia gender..., s. 300-303.

55 Por. Marek Bieńczyk, Melancholia. O tych, co nigdy nie odnajda straty, Warszawa 2012.

56 Na sopockiej wystawie, obok Gertrudy Wysockiej - przodownicy pracy, zawisł, zbliżony zarówno w ujęciu, jak i formacie, Gogol Studnickiego z 1952 r. (olej, pł., $144 \times 167$ cm, Muzeum Narodowe w Warszawie, wyróżniony nagrodą na III Ogólnopolskiej Wystawie Plastyki). Oba portrety, o Manetowskim wyrazie, mają szczególny alegoryzujący rys - poza Gogola oraz sztafaż przedstawienia pozwalają interpretować portret jako figurę melancholii. 


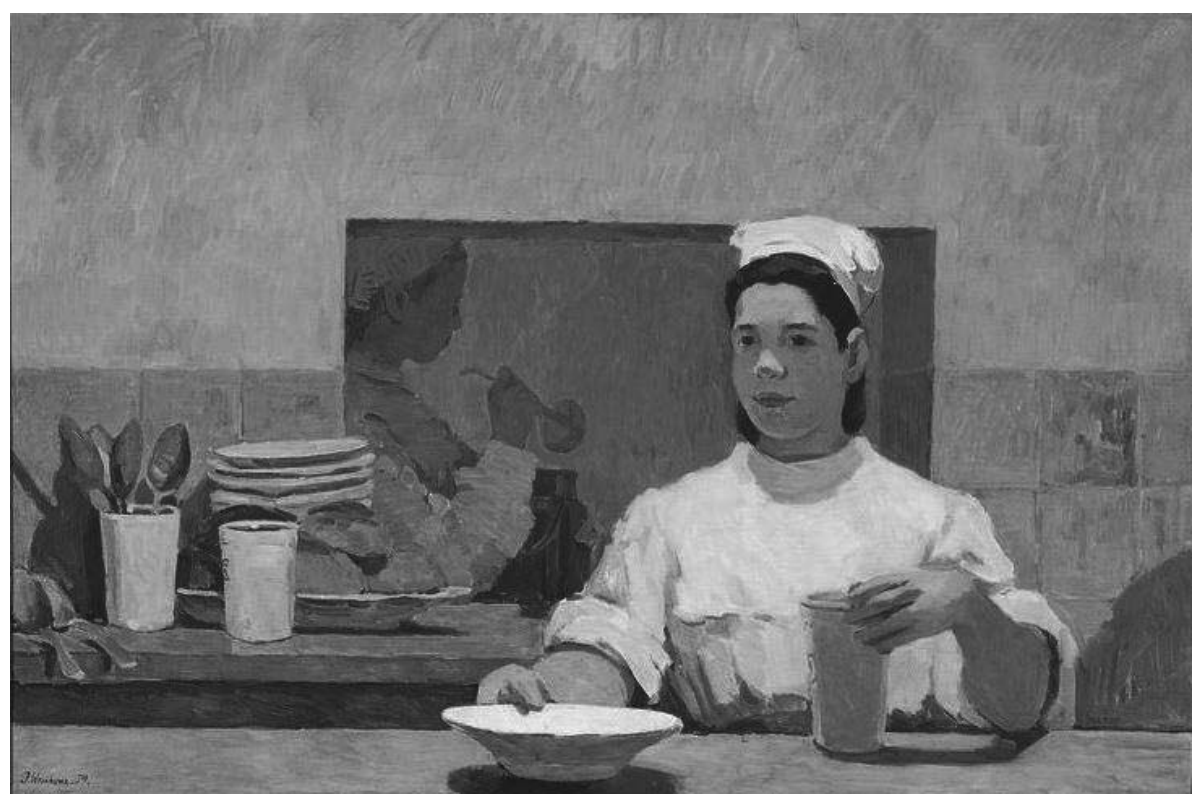

Il. 5. Józefa Wnukowa, Bar mleczny, 1954, olej, płótno, $73 \times 118$ cm, Muzeum Narodowe w Warszawie, fot. ze zbiorów autora

podobieństwo rybich kształtów - odnosi widza do męskości i życia seksualnego, choć niejednokrotnie też do chłodu seksualnego i obojętności płciowej, chciwości, ale i niezdarności ${ }^{57}$. Dwoistość w postrzeganiu ryby sprawiała, że już w antyku ujmowano ją jako „wrzeciono przędące zgodnie z księżycowym zodiakiem cykl $\dot{z}_{y c i a}{ }^{\prime \prime}$. Przedstawienia kobiet patroszących ryby były powszechne w malarstwie holenderskim (zwłaszcza w intymistycznej szkole malarstwa lejdejskiego drugiej połowy XVII w., tzw. fijnschilders) ${ }^{59}$ (il. 6-7). Wyobrażenia ryb, połowów czy rybaków w nowożytnym języku emblematycznym odnoszono do ikonografii temperamentów ludzkich. Poprzez związanie z żywiołem wody kojarzono je z ospałością, lenistwem, człowiekiem flegmatycznym ${ }^{60}$ (il. 8).

57 Zob. Władysław Kopaliński, Słownik symboli, Warszawa 1990, s. 364-365.

58 Marius Schneider, El origen musical de los animales-símbolos en la mitología y la escultura antiguas, Madryt 1997; cyt. za: Juan Eduardo Cirlot, Słownik symboli, Kraków 2006, s. 354.

59 Zwłaszcza niektóre obrazy Gabriëla Metsu (np. Kobieta czyszcząca ryby, 1656-1658, olej, pł., 30,5 × 27,3 cm, Metropolitan Museum of Art, Nowy Jork), Quirijna Gerritsz van Brekelenkama (Stużąca patroszaca ryby widziana przez okno, około 1650 , olej, płótno, $31,8 \times 28,7 \mathrm{~cm}$, zbiory prywatne) czy Willema van Mierisa. Andrzej Zagrobelny w omówieniu twórczości Studnickiego zwrócił uwagę na powiązania obrazu Gertruda Wysocka - przodownica pracy z ikonografią malarstwa niderlandzkiego XVI i XVII w., m.in. z obrazami Pietera Aertsena, Joachima Beuckelaera, Fransa Snydersa, zob. Zagrobelny, Życie i twórczość..., s. 101.

60 Por. Janina Michałkowa, Nieokreślony malarz holenderski, XVII w. Rybak [w:] Ars emblematica. Ukryte znaczenia w malarstwie holenderskim XVII w. [katalog wystawy], Muzeum Narodowe w Warszawie, Warszawa 1981, s. 113-114, poz. kat. 37. 


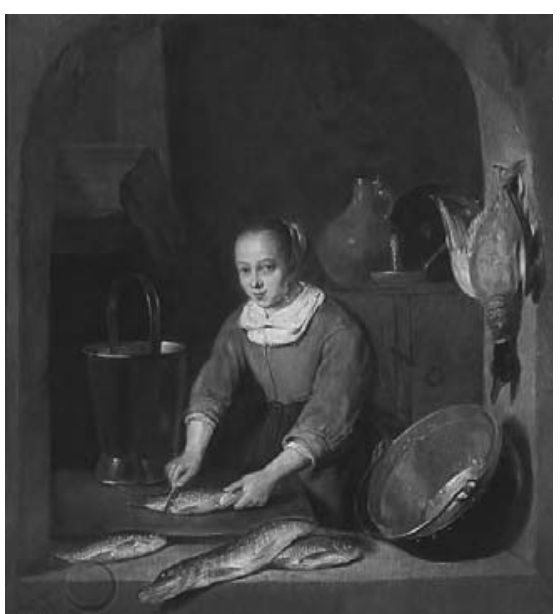

Il. 6. Quirijn Gerritsz van Brekelenkam, Stużąca patroszaca ryby widziana przez okno, około 1650, olej, płótno, $31,8 \times 28,7 \mathrm{~cm}$, zbiory prywatne, fot. ze zbiorów autora

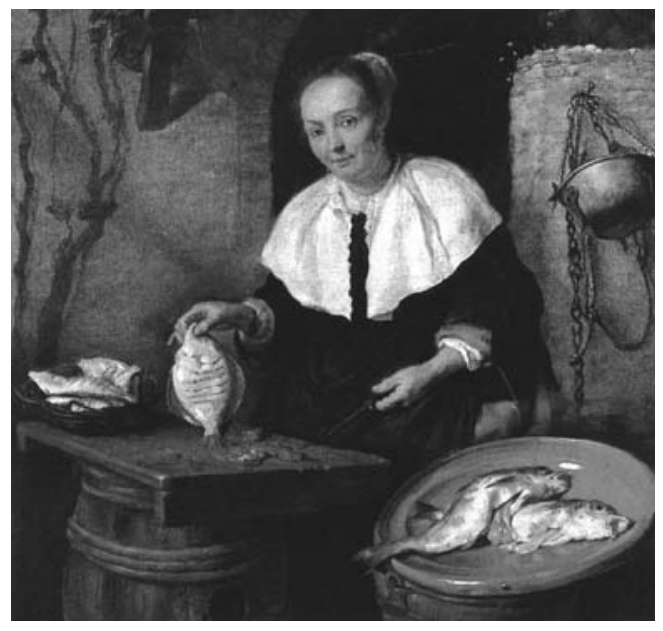

Il. 7. Gabriël Metsu, Kobieta czyszcząca ryby, 1656-1658, olej płótno, $30,5 \times 27,3 \mathrm{~cm}$, Metropolitan Museum of Art w Nowym Jorku, fot. ze zbiorów autora

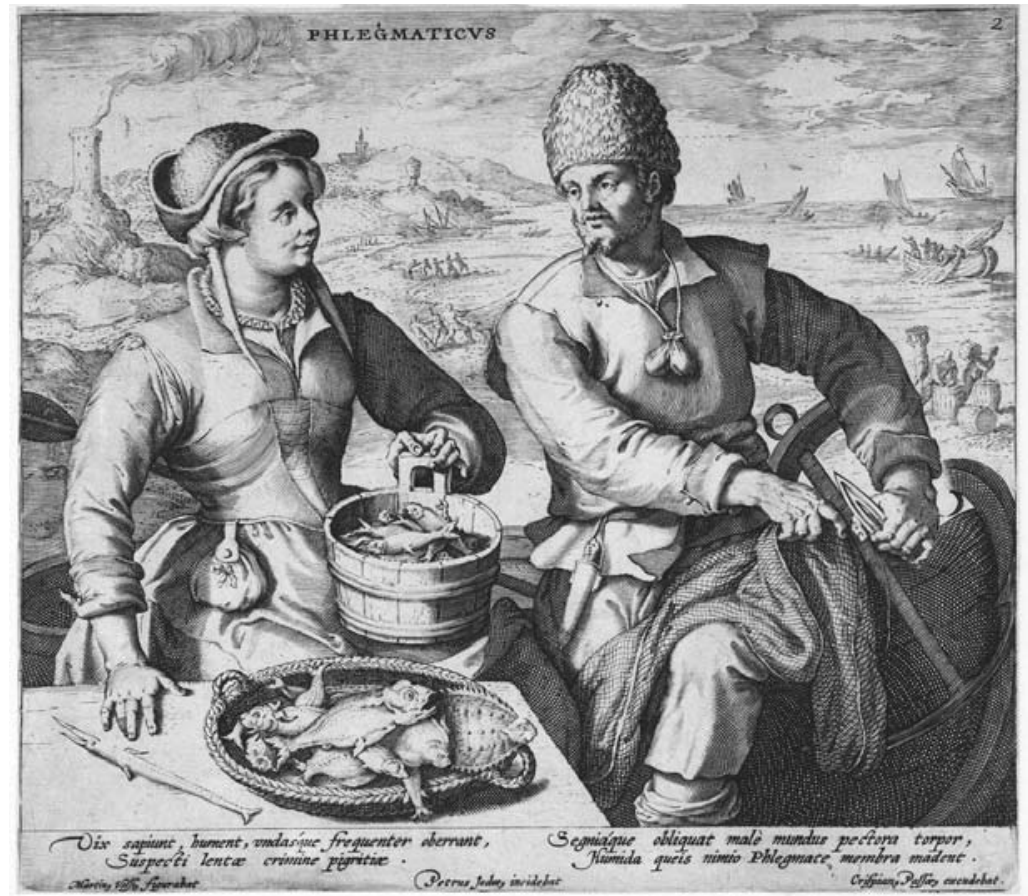

Il. 8. Pieter de Jode I (wg Maartena de Vos), Temperament flegmatyczny, około 1595-1599, akwaforta, 19,4 ×22,2 cm, Museum Boijmans Van Beuningen w Rotterdamie, fot. ze zbiorów autora 


\begin{abstract}
Alegoria realna
Produkcja obrazowa kilkuletniego zaledwie epizodu socrealistycznego w sztuce polskiej była nacechowana społeczno-politycznymi napięciami oraz nierozstrzygalnymi ideowo-artystycznymi antynomiami: między wolnością a uwikłaniem, kompromisem a konformizmem ${ }^{61}$, naiwnością a wyrachowaniem, szczerością a cynizmem, doktrynalnością a pragmatyzmem, optymizmem a poczuciem mizerii, zaangażowaniem a eskapizmem. Powstające w latach 1949-1955 obrazy były w przytłaczającej większości schematyczne i sztampowe, lecz również rozbrajająco nieporadne bądź niezamierzenie wydumane, mierne i mizerne - rzec można. Na tym
\end{abstract} tle Gertruda Wysocka - przodownica pracy sytuuje się jako obraz wyjątkowy z kilku powodów - ze względu na niepoślednie wartości stricte malarskie; jawne nawiązania do tradycji obrazowej, szczególnie zaś do jednego ze źródłowych obrazów artystycznej nowoczesności; wreszcie, ze względu na swoistą ambiwalencję, by nie powiedzieć - paradoksalność wizualnego ujęcia oraz nieoczywistych, a może nawet sprzecznych znaczeń. Owo swoiste „zasysanie” pożywek - by posłużyć się sugestywną formułą Kępińskiego - „to nieprzerwany pas transmisyjny ewolucji gatunku ludzkiego. To koło zębate historii, zdolne pracować tylko wtedy, kiedy zazębia się

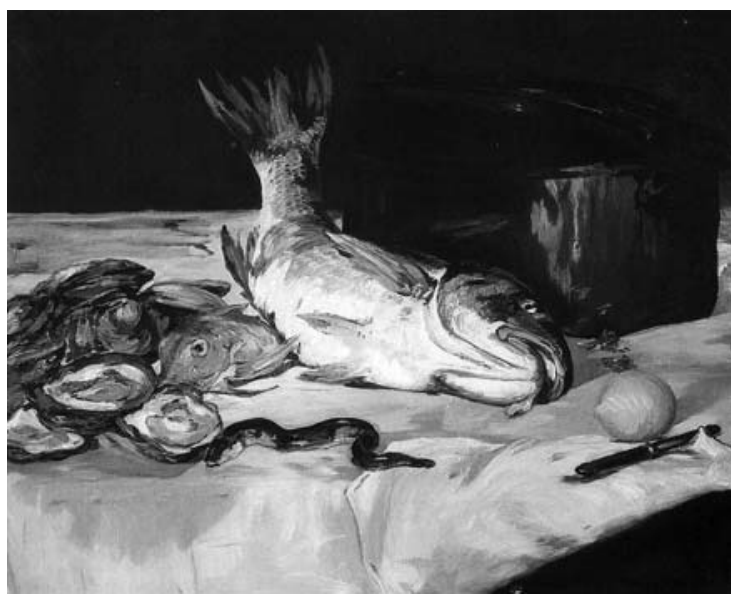

Il. 9. Édouard Manet, Ryby (Martwa natura), 1864, olej, płótno, 73,4 ×92,1 cm, Art Institute w Chicago, repr. za: Wikipedia o inne tryby tego samego, »swojego « mechanizmu"62 (il.9). Tym bardziej że wbrew uznawanym za słuszne i wzorcowe doświadczeniom ówczesnej sztuki radzieckiej, pomimo postulowanych nawiązań do realistycznych tradycji oraz deklarowanego powszechnie ideowego zaangażowania, obraz Studnickiego odwołuje się raczej do idiomu „nowoczesnego" malarstwa w jego modernistycznym (francuskim) ujęciu. Prowadziło ono do wycofania się sztuki w obszary własnej autonomii, uwolnienia jej od wymogów i powinności pozaartystycznych, a zmierzającym do postępującego usamodzielnienia i wyzwolenia istoty obrazu jako autonomicznej rzeczywistości artystycznej o swoistym „nierealnym” charakterze, przeznaczonym dla nowoczesnej społeczności złożonej z wolnych jednostek. Ta liberalna postawa,

61 Por. Hubert Bilewicz, Szkoła sopocka: między kompromisem a konformizmem [w:] Sztuka w kręgu władzy. Materiały LVII Ogólnopolskiej Sesji Naukowej Stowarzyszenia Historyków Sztuki poświęconej pamięci Profesora Szczęsnego Dettloffa (1878-1961) w 130. rocznicę urodzin, Toruń, 13-15 listopada 2008, red. Elżbieta Pilecka, Katarzyna Kluczwajd, Warszawa 2009, s. 367-378.

62 Kępiński, Impresjoniści u źródeł..., s. 65. 
Hubert właściwa dla modernizmu artystycznego, akcentująca cele czysto artystyczne, Bilewicz podkreślała jednak silny związek postępowości artystycznej ze społecznymi tendencjami emancypacyjnymi i polityczną walką o wyzwolenie narodowe czy społeczne ${ }^{63}$. Działo się to wszystko - dodajmy - pośród nawoływań do przełamania tej „francuskiej choroby” oraz „uwolnienia się od kompleksu, że malarstwo nasze popadnie w barbarzyńskość, jeśli przestaniemy je mierzyć francuską miarą" ${ }^{64}$.

Jeśli nawet wyjdziemy z założenia, że za decyzjami artystycznymi Studnickiego związanymi z przyjęciem takiej, a nie innej formuły przedstawieniowej stały przede

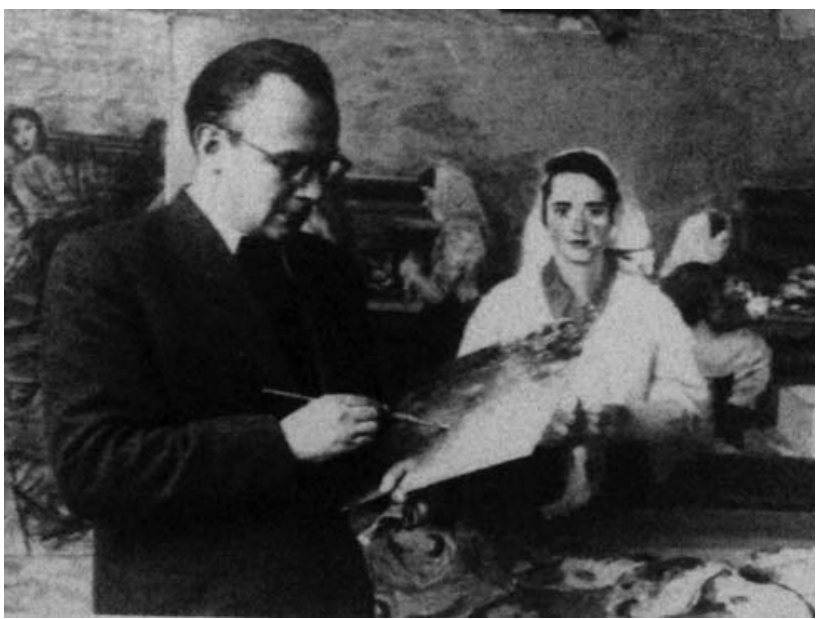

Il. 10. Juliusz Studnicki na tle obrazu Gertruda Wysocka przodownica pracy, fot. ze zbiorów prywatnych wszystkim względy formalne (kompozycyjno-stylistyczne), to nie sposób uznać, że artysta nie brał pod uwagę kwestii tematyki (z całym jej potencjałem aktualizacyjnym) czy metaforyki (wraz ze ścisłymi odniesieniami alegorycznymi). Dotyczy to zarówno strategii artystycznych samego twórcy, jak i stylów odbioru tego obra$\mathrm{zu}$ (il. 10).

Obraz Gertruda Wysocka przodownica pracy nie jest oczywisty, a jego alegoryczność nie ma charakteru jednoznacznego, co przecież można uznać za sprzeczne z samą ideą alegorii. Niemniej wyjątkowość tego obrazu tkwi właśnie w jego paradoksalności, bliskiej Courbetowskiemu ujęciu Atelier, kolejnego paradygmatycznego obrazu nowoczesności, opatrzonego przecież symptomatycznym podtytułem Alegoria realna ${ }^{65}$.

\section{Bibliografia}

Araszkiewicz Agata, Kobieta z marmuru [w:] Maria Papa Rostkowska. Kobieta z marmuru [katalog wystawy], Warszawa 2014, s. 57.

Berger John, Sposoby widzenia, Poznań 1997.

Bieńczyk Marek, Melancholia. O tych, co nigdy nie odnajda straty, Warszawa 2012.

63 Por. Stephen F. Eisenman, et al., Nineteenth Century Art. A Critical History, London 2011.

${ }^{64}$ Henryk Gotlib, Potrzeba przemian w malarstwie polskim, „Materiały do Studiów i Dyskusji" 1950, t. 2, s. 88.

65 Obraz Courbeta Pracownia malarza: alegoria realna siedmiu lat mego życia jako artysty, bo tak brzmi jego pełny tytuł, z Barem w Folies-Bergère Maneta zestawiała już Linda Nochlin, The Invention of the Avant-Garde..., s. 17. 
Bilewicz Hubert, Nostalgia i mizeria socrealizmu: „Gertruda Wysocka - przodownica pracy” Juliusza Studnickiego jako alegoria realna [w:] Juliusz Studnicki (1906-1978). Twórcy i założyciele szkoły sopockiej, red. Andrzej Zagrobelny [katalog wystawy], Muzeum Sopotu, Sopot 2015, s. 28-35.

Bilewicz Hubert, Szkoła sopocka: między kompromisem a konformizmem [w:] Sztuka $w$ kregu władzy. Materiały LVII Ogólnopolskiej Sesji Naukowej Stowarzyszenia Historyków Sztuki poświęconej pamięci Profesora Szczęsnego Dettloffa (1878-1961) w 130. rocznicę urodzin, Toruń, 13-15 listopada 2008, red. Elżbieta Pilecka, Katarzyna Kluczwajd, Warszawa 2009, s. 367-378.

Bogucki Janusz, Wystawa „Plastycy w walce o pokój”, „Przegląd Artystyczny” 1951, nr 1, s. 26-27.

Boime Albert, Manet's „Un bar aux Folies-Bergère” as an AllegoryofNostalgia, „Zeitschrift für Kunstgeschichte" 1993, nr 2, s. 234-248.

Chowaniec Urszula, Melancholia [w:] Encyklopedia gender. Płeć w kulturze, red. Monika Rudaś-Grodzka i in., Warszawa 2014, s. 300-303.

Cirlot Juan Eduardo, Słownik symboli, Kraków 2006.

Clark Timothy James, The Painting of Modern Life. Paris in the Art of Manet and His Followers, Princeton 1999.

Dobrowolski Tadeusz, Nowoczesne malarstwo polskie, t. 3, Wrocław 1964, s. 416-417.

Dzienis Magdalena, Przyczynek do badania wizerunku kobiety-robotnicy, przodowniczki pracy $w$ prasie $w$ okresie realizacji Planu 6-letniego [w:] Współzawodnictwo pracy $w \dot{z} y c i u$ gospodarczym, społeczno-politycznym i propagandzie PRL, red. Bogusław Tracz, Warszawa 2008, s. 221-229.

Eisenman Stephen F., et al., Nineteenth Century Art. A Critical History, London 2011.

Fidelis Małgorzata, Kobiety, komunizm i industrializacja w powojennej Polsce, Warszawa 2015.

Friszke Andrzej, Przystosowanie i opór. Rozważania nad postawami społecznymi 1956-1970 [w:] idem, Przystosowanie i opór. Studia z dziejów PRL, Warszawa 2007, s. $137-138$.

Głowiński Michał, Kierunek: wielka nomenklaturowa chałtura [w:] idem, Rytuał i demagogia. Trzynaście szkiców o sztuce zdegradowanej, Warszawa 1992, s. 163.

Głowiński Michał, Realizm i demagogia [w:] idem, Rytuał i demagogia. Trzynaście szkiców o sztuce zdegradowanej, Warszawa 1992, s. 17.

Gotlib Henryk, Potrzeba przemian w malarstwie polskim, „Materiały do Studiów i Dyskusjii" 1950, t. 2, s. 88.

Grabska Elżbieta, „Puisque réalisme il y a”, czyli o tym, co w sztuce powojennego dziesięciolecia nie mogło się dokonać [w:] Sztuka polska po 1945 roku. Materiały Sesji Stowarzyszenia Historyków Sztuki, Warszawa, listopad 1984, Warszawa 1987, s. 376.

Haake Michał, Portret w malarstwie polskim u progu nowoczesności, Kraków 2008.

Ilkosz Jerzy, Malarstwo realizmu socjalistycznego w Polsce [w:] Sztuka polska po 1945 roku. Materiały Sesji Stowarzyszenia Historyków Sztuki, Warszawa, listopad 1984, Warszawa 1987, s. 206.

Jarmułowicz Małgorzata, Przodownika pracy obraz [w:] Słownik realizmu socjalistycznego, red. Zdzisław Łapiński, Wojciech Tomasik, Kraków 2004, s. 240.

Kal Elżbieta, Malarstwo gdańskie 1945-1959. Ludzie, słowa i obrazy, Słupsk 2009. 
Hubert Kaźmierczyk Zbigniew, Ewolucja romantycznego tytanizmu $w$ ikonografii socrealiBilewicz stycznej-na przykładzie utworów Aleksandra Ścibora-Rylskiego [w:] Socrealizm. Fabuly - komunikaty - ikony, red. Krzysztof Stępnik, Magdalena Piechota, Lublin 2006, s. 147.

Kenney Padraic, Budowanie Polski Ludowej. Robotnicy a komuniści 1945-1950, Warszawa 2015.

Kępiński Zdzisław, Impresjoniści u źródeł swych obrazów, Wrocław 1976.

Kopaliński Władysław, Słownik symboli, Warszawa 1990.

Krajewski Juliusz, I Ogólnopolska Wystawa Plastyki, „Przegląd Artystyczny” 1950, nr 5-6, s. 19. Kurz Iwona, Alegoria [w:] Encyklopedia gender. Płeć w kulturze, red. Monika Rudaś-Grodzka i in., Warszawa 2014, s. 32-33.

Michałkowa Janina, Nieokreślony malarz holenderski, XVII w. Rybak [w:] Ars emblematica. Ukryte znaczenia $w$ malarstwie holenderskim XVII w. [katalog wystawy], Muzeum Narodowe w Warszawie, Warszawa 1981, s. 113-114.

Mitchell W.J.T., Czego chca obrazy?, Warszawa 2013.

Nochlin Linda, Realizm, Warszawa 1974.

Nochlin Linda, The Invention of the Avant-Garde [w:] eadem, The Politics of Vision. Essays on Nineteenth-Century Art and Society, New York 1989, s. 17.

Oblicza socrealizmu, red. Maryla Sitkowska [katalog wystawy], Muzeum Narodowe w Warszawie, Warszawa 1987.

Państwowa Wyższa Szkoła Sztuk Plastycznych w Gdańsku, 1945-1965, red. Józefa Wnukowa [b.m., b.d.].

Plastycy polscy $w$ walce o pokój, „Słowo Ludu” 1950, nr 322, s. 6.

Pollock Griselda, Vision and Difference. Femininity, Feminism and the Histories of Art, London-New York 1988.

Polskie życie artystyczne w latach 1944-1960, red. Anna Wierzbicka, t. 4, Rok 1950, oprac. Przemysław Strożek, Warszawa 2012.

Radkiewicz Małgorzata, Władza spojrzenia [w:] Encyklopedia gender. Płeć w kulturze, red. Monika Rudaś-Grodzka i in., Warszawa 2014, s. 567.

Rassalski Stefan, Wystawa Przodowników Pracy, „Stolica” 1950, nr 31, s. 9.

Schneider Marius, Elorigen musical de los animales-símbolosen la mitología y la esculturaantiguas, Madryt 1997.

Skalska Agnieszka, „Dziewczynka z chryzantemami” Olgi Boznańskiej - osaczona. Uwagi o spojrzeniu, „Artium Quaestiones” 1995, nr 7, s. 141-151.

Sitkowska Maryla, Czytanie między obrazami, „Res Publica” 1987, nr 4, s. 37.

Studzińska Jolanta, Socrealizm w malarstwie polskim, Warszawa 2014, s. 567.

Tomczyk-Watrak Zofia, Wybory i przemilczenia. Od szkoły sopockiej do nowej szkoły gdańskiej, Gdańsk 2001.

Toniak Ewa, Olbrzymki. Kobiety i socrealizm, Kraków 2008.

Warner Marina, Monuments and Maidens. The Allegory of the Female Form, New York 1985.

Wilk Hubert, Kto wyrąbie więcej ode mnie? Współzawodnictwo pracy robotników w Polsce w latach 1947-1955, Warszawa 2011.

Wilk Hubert, Ludzie z marmuru. Proces awansu i degradacji przodowników pracy (1947-1955) [w:] Współzawodnictwo pracy w życiu gospodarczym, społeczno-politycznym i propagandzie PRL, red. Bogusław Tracz, Warszawa 2008, s. 69-93. 
Włodarczyk Wojciech, Socrealizm. Sztuka polska w latach 1950-1954, Kraków 1991.

Zagrobelny Andrzej, Twórczość Juliusza Studnickiego w okresie dwudziestolecia międzywojennego, „Porta Aurea” 2012, t. 11, s. 301-319.

Zagrobelny Andrzej, Życie i twórczość Juliusza Studnickiego (1906-1978), mpis pracy mgr napisanej pod kierunkiem Joanny Sosnowskiej, Gdańsk 2010.

Ziemba Antoni, Alegoria [w:] Słownik terminologiczny sztuk pięknych. Wydanie nowe, Warszawa 1996, s. 10.

\section{Nostalgy and Mysery of Socialist Realism, „Gertruda Wysocka: Heroine of Socialist Labour”, by Juliusz Studnicki as Real Allegory}

The paper is dedicated to one of the most outstanding works created in 1950 within the circle of the Sopot School, while at the same time one of the most interesting paintings of Polish Socialist Realism. Visual interpretation as well as historical-artistic interpretations focus on genealogical questions (reminiscence and paraphrase of $A$ Bar at the Folies-Bergère by Edouard Manet, as well as references to $17^{\text {th }}$-century genre-allegorical representations of the Leiden School genre-related questions (portrait, genre scene, or allegory?), iconographic issues (representations of heroes of Socialist labour, iconography of temperaments), as well as stylistic ones (Socialist Realism versus Manet's modernized realism). The formulated methodological interpretations have been defined by Gottfried Boehm's existential hermeneutics of portrait, W.J.T. Mitchell's animist iconology, intertextual perspective, and feminist-gender approach. 